\title{
Rodzaje cięcie laserowego
}

\section{Kind of laser cutting processes}

\section{Streszczenie}

Cięcie laserowe jest najpopularniejszą techniką cięcia termicznego stosowanego w przemyśle. W celu uzyskania oczekiwanej jakości cięcia istotny jest prawidłowy dobór parametrów lasera i rodzaju ciecia do danego materiału poddawanego obróbce. W pracy zawarto charakterystykę podstawowych rodzajów cięcia laserowego oraz możliwości ich zastosowania do poszczególnych grup materiałów

Słowa kluczowe: cięcie laserowe, cięcie materiałów konstrukcyjnych, laser

\section{Abstract}

The laser cutting is the most popular thermal cutting technique used in the industry. In order to obtain the desired quality of cut the correct choice of laser parameters and the type of cut to the material to be treated is very important. Therefore, the paper contains the characteristics of the main types of laser and their applicability to particular groups of materials.

Keywords: laser cutting, cutting of structural materials, laser

\section{Wstęp}

Cięcie laserowe jest procesem, w którym energia wiązki laserowej padającej na powierzchnię obrabianego materiału powoduje stopienie i spalenie, stopienie, bądź odparowanie ciętego materiału $[1 \div 10]$. Proces ten może być prowadzony ręcznie (bardzo rzadko), zaś przemyśle stosowane są głównie układy cięcia automatycznego i zrobotyzowanego ze sterowaniem numerycznym i możliwością cięcia trójwymiarowego.

Promieniowanie laserowe może być generowane $w$ trybie ciągłym bądź impulsowym, w zależności od konstrukcji urządzenia. Obecnie większość urządzeń pracuje w trybie impulsowym, a moc średnia regulowana poprzez częstotliwość generowania impulsów. W celu zwiększenia gęstości mocy wiązka laserowa ogniskowana jest do plamki poniżej $0,5 \mathrm{~mm}$ przy pomocy głowicy soczewkowej bądź zwierciadlanej.

Wymagana gęstość mocy promieniowania laserowego w procesie cięcia mieści się w zakresie 104-106 W/mm² w zależności od rodzaju ciętego materiału. Przy zachowaniu tych zależności podczas procesu następuje natychmiastowe topienie i odparowywanie ciętego materiału w szczelinie cięcia. Wiązka laserowa działa jako liniowe źródło energii cięcia, przetapiając materiał na całej grubości. Ważna jest również polaryzacja wiązki, która wpływa na sprawność procesu cięcia oraz jakość krawędzi cięcia. W zależności od konstrukcji lasera możliwa jest polaryzacja liniowa, eliptyczna, kołowa i losowa. Przy polaryzacji liniowej i eliptycznej jakość cięcia zależy od kierunku cięcia, natomiast polaryzacja kołowa zapewnia jednakową jakość cięcia w każdym kierunku i jest najczęściej stosowana w wykrawarkach laserowych [11].

W zależności od ciętego materiału i oczekiwanego efektu obróbki, proces cięcia laserowego może być realizowany przy użyciu gazów roboczych takich jak:

- tlen (stosowany głównie do cięcia gazowego i laserowego stali niestopowych i niskostopowych),

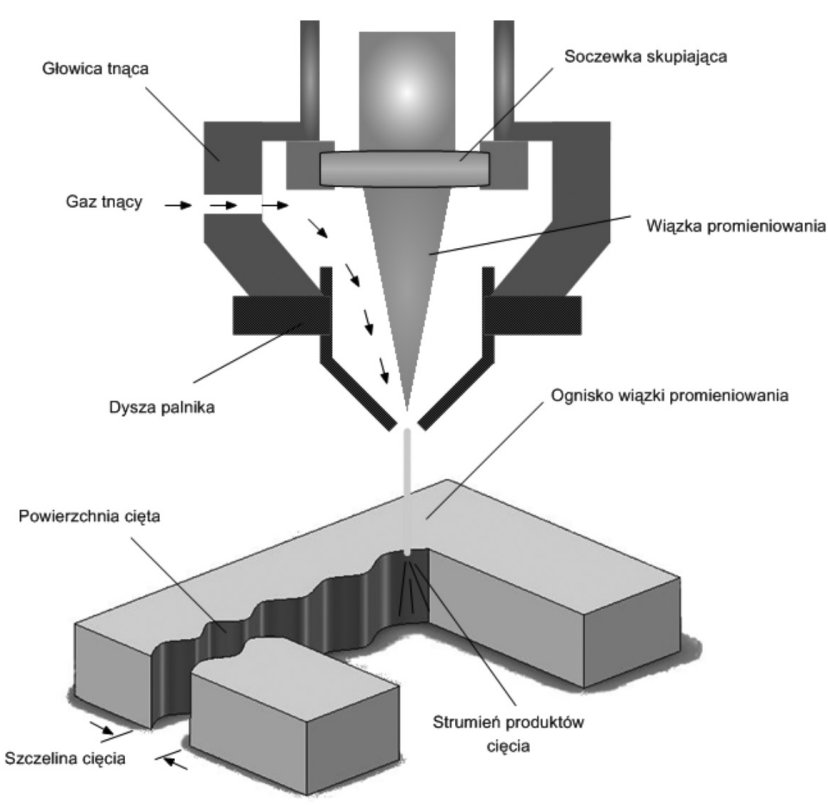

Rys. 1. Schemat cięcia laserowego

Fig. 1. Laser cutting scheme

- azot (stosowany do cięcia stali wysokostopowych i materiałów niemetalicznych),

- argon (stosowany do cięcia tytanu i stali wysokostopowych). Zalety cięcia laserowego:

- minimalna strefa wpływu ciepła w porównaniu do innych technologii cięcia termicznego,

- duża prędkość cięcia i wysoka jakość ciętych krawędzi,

- proces przebiega bezdotykowo, nie występuje zjawisko zużywania narzędzi,

- gładka i czysta powierzchnia cięcia, zbędna jest dodatkowa obróbka wykańczająca,

- oszczędność materiału poprzez uzyskiwanie wąskiej szczeliny cięcia,

Dr inż. Paweł Kołodziejczak - Instytut Technik Wytwarzania, Politechnika Warszawska. 


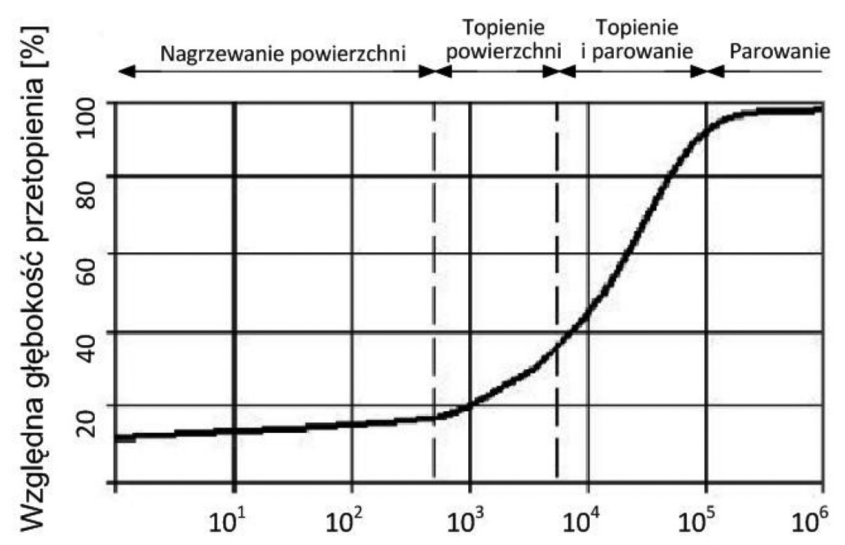

Gęstość mocy wiązki laserowej $\left[\mathrm{W} / \mathrm{mm}^{2}\right]$

Rys. 2. Wpływ gęstości mocy wiązki laserowej na głębokość przetopienia oraz zjawisko topienia i parowania metali w szczelinie cięcia [11] Fig. 2. The influence of power density of the laser beam to a depth of melting and the phenomenon of melting and evaporation of metals [11]

- łatwość pełnej automatyzacji, co umożliwia proste sterowanie przebiegiem produkcji i integrację z innymi systemami,

- możliwość cięcia prawie każdego materiału,

- niski jednostkowy koszt wytwarzania,

- możliwość ukosowania na V i Y,

- elastyczność przy zmianie profilu, kształtów oraz typorozmiarów produkcji,

- niezastąpiona technologia przy produkcji prototypowej na etapie projektowania, testowania i doskonalenia konstrukcji samochodów,

- prosta regulacja mocy lasera pozwalająca uzyskać wyższą jakoś cięcia.

Wady cięcia laserowego

- wysoki koszt inwestycyjny,

- ze względów jakościowych ograniczona jest grubość ciętej blachy,

- specjalne wymagania dotyczące jakości powierzchni ciętych materiałów.

Przewaga zalet ciecia laserowego sprawia, że laser w wielu przypadkach staje się jedynym i niezastąpionym narzędziem mogącym sprostać obecnym wymogom.

Jakość cięcia laserowego w bezpośredni sposób zależy od parametrów procesu, takich jak: mod promieniowania, współczynnik jakości wiązki BPP, rodzaju gazu tnącego, średnicy dyszy doprowadzającej gaz, średnicy wiązki w ognisku, położenia ogniska i prędkości cięcia. Poza ww. parametrami na dokładność cięcia - wysoki stopnień utrzymywania wymiarów ciętych elementów konstrukcyjnych wpływa dokładność prowadzenia wiązki laserowej w połączeniu ze stabilną obrabiarką do cięcia, o dobrej jakości, dużej odporności na drgania i wysokiej powtarzalności. Nie bez znaczenia pozostają także właściwości ciętego materiału, a w szczególności absorpcja i przewodność cieplna, których przykładowe wartości zamieszczono w tablicy I.

\section{Odmiany cięcia laserowego}

Zastosowanie technologii cięcia laserowego zależy w dużym stopniu od właściwości ciętego materiału, parametrów procesu cięcia oraz rodzaju gazu tnącego zastosowanego w procesie. W zależności od tych właściwości i parametrów wyróżnia się trzy podstawowe odmiany cięcia:

- cięcie ze spalaniem materiału,

- cięcie ze stapianiem i wydmuchiwaniem materiału,

- cięcie z odparowaniem materiału.

Metody w sensie technologicznym różnią się między sobą głównie rodzajem i sposobem zastosowania gazu roboczego. Gaz i zogniskowana wiązka lasera równorzędnie stanowią czynnik decydujący o przebiegu i wynikach procesu cięcia. [12]

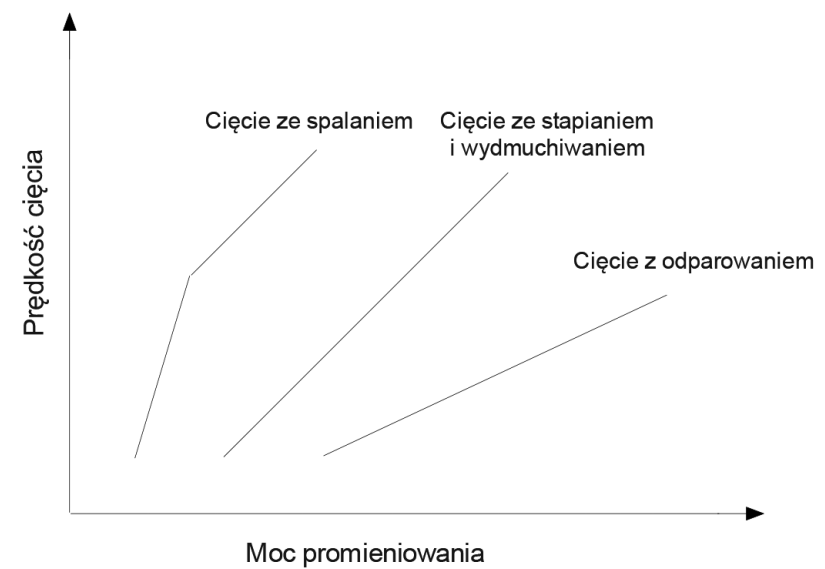

Rys. 3. Zależność prędkości cięcia i mocy wyjściowej lasera przy różnych mechanizmach usuwania produktów cięcia ze szczeliny [13] Fig. 3. The influence of the cutting velocity and the laser power with different mechanisms of removal of the cutting products [13]

Oprócz przedstawionych rodzajów cięcia laserowego do materiałów o szczególnych właściwościach można zastosować następujące odmiany cięcia laserowego:

- generowanie pęknięć termicznych (stosowane do cięcia szkła lub innych materiałów kruchych),

- zarysowanie (polega na wykonaniu przez laser nacięcia a następnie łamaniu mechanicznym, stosowany do obróbki płytek korundowych),

- zimne cięcie (stosowane do obróbki tworzyw sztucznych). [13]

\section{Proces cięcia laserowego ze spalaniem materiału}

Proces cięcia laserowego ze spalaniem materiału może zachodzić tylko wtedy kiedy jako gaz tnący stosujemy tlen. Ten rodzaj cięcia jest bardzo zbliżony do cięcia acetylenowo-tlenowego, ponieważ cięty materiał spala się w szczelinie cięcia pozostawiając płynny żużel, który zostaje wydmuchiwany z obszaru cięcia (rys. 4).

Wiązka zogniskowanego promieniowania laserowego pada na powierzchnię ciętej stali nagrzewając ją w obszarze szczeliny cięcia do temperatury zapłonu (dla stali konstrukcyjnej od 1150 do $1200^{\circ} \mathrm{C}$ ), następnie dostarczany jest tlen

Tablica I. Wybrane właściwości różnych matali (niepolerowanych) [14] Table I. Selected properties of various metals (unpolished)

\begin{tabular}{|c|c|c|c|}
\hline Metal & Absorpcja [\%] & Przewodność cieplna [W/m/K] & Temperatura topnienia [ ${ }^{\circ} \mathrm{C}$ ] \\
\hline Złoto & $0,5-1,0$ & 296 & 1067 \\
Srebro & $0,5-1,0$ & 419 & 957 \\
Miedź & $1,0-2,0$ & 385 & 1083 \\
Aluminium & $1,0-2,0$ & 201 & 659 \\
Żelazo & około 5,0 & 80 & 1537 \\
Nikiel & około 6,0 & 59 & 1453 \\
Tytan & około 8,5 & 23 & 1677 \\
\hline
\end{tabular}


w celu zintensyfikowania procesu spalania. Cięcie ze spalaniem pozwala na uzyskanie stosunkowo dużej prędkości cięcia i wykorzystywane jest tylko do obróbki stali niestopowych i niskostopowych. Prędkość cięcia w bezpośredni sposób zależy od mocy zastosowanego lasera i od grubości ciętych materiałów. Bezpośredni wpływ na jakość cięcia ma także średnica dyszy (której średnica rośnie wraz ze wzrostem grubości ciętej stali) i ciśnienie tlenu tnącego (które maleje wraz ze wzrostem średnicy dyszy).

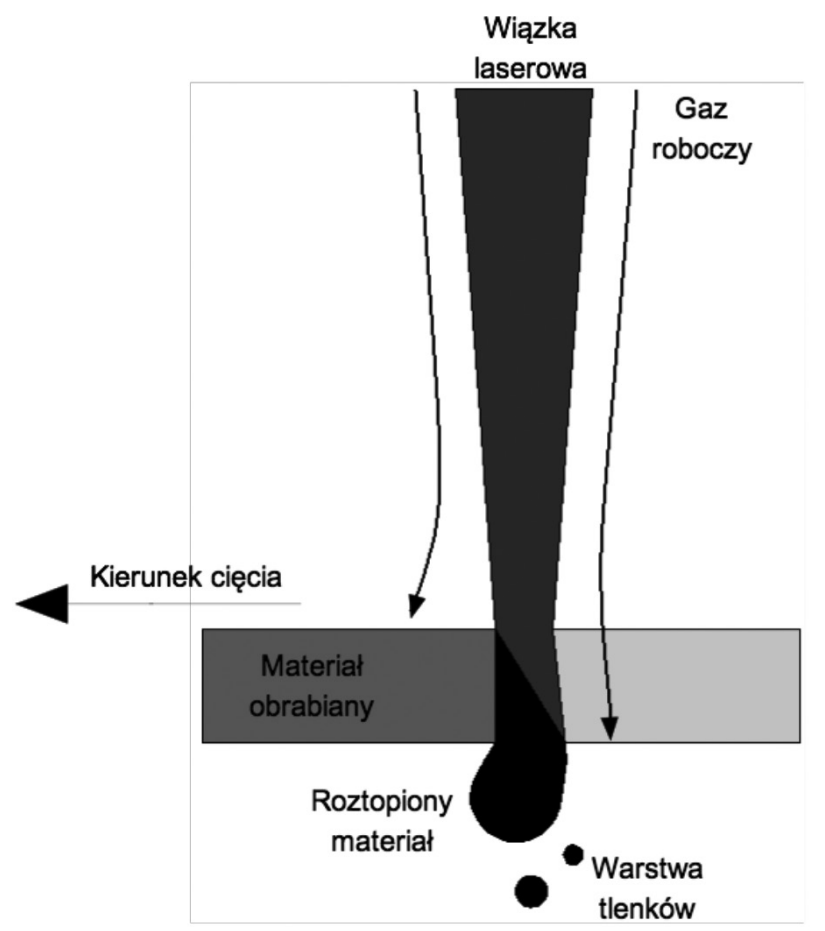

Rys. 4. Schemat procesu cięcia laserowego ze spalaniem materiału Fig. 4. A schematic of laser flame cutting process

\section{Proces cięcia laserowego}

ze stapianiem i wydmuchiwaniem materiału

Podczas procesu cięcia ze stapianiem i wydmuchiwaniem materiału energia potrzebna do topienia pochodzi tylko z promieniowania laserowego (gęstość mocy wynosi ok. $10^{1}-10^{2} \mathrm{~kW} / \mathrm{mm}^{2}$ ) gdyż gaz roboczy nie reaguje egzotermicznie z materiałem jak w przypadku ciecia ze spalaniem [3]. Wysoka moc lasera pozwala na doprowadzenie materiału znajdującego się na ścieżce cięcia do płynnej postaci, a następnie usuniecie go ze szczeliny cięcia za pomocą gazu technicznego (azot bądź argon). Brak spalania powoduje powstawanie powierzchni wolnych od tlenków co jest pożądane podczas obróbki stali wysokostopowych i metali nieżelaznych. W celu uzyskania czystych powierzchni stosowany jest wysokie ciśnienie gaz (8-29 bar). Stosowanie tak wysokiego ciśnienia gazu tnącego oznacza również konieczność używania specjalnych, wysokociśnieniowych głowic tnących.

\section{Proces cięcia laserowego $\mathbf{z}$ odparowaniem materiału}

Cięcie laserowe z odparowaniem materiału zachodzi w wysokiej temperaturze, a co za tym idzie przy wysokiej gęstości mocy wiązki $\left(10^{2}-10^{3} \mathrm{~kW} / \mathrm{mm}^{2}\right)$, powodującej gwałtowne nagrzewanie powierzchni materiału w obszarze cięcia do temperatury wrzenia i w konsekwencji doprowadzenie części ciętego materiału do stanu gazowego. W miejscu cięcia powstaje kapilara wypełniona parami ciętego materiału, powodując znaczne zwiększenie współczynnika absorpcji na skutek wielokrotnego odbicia od jej ścianek, skutkując penetracją kanału w głąb ciętego materiału prowadząc do całkowitego jego przebicia. Procesy gazodynamiczne za-

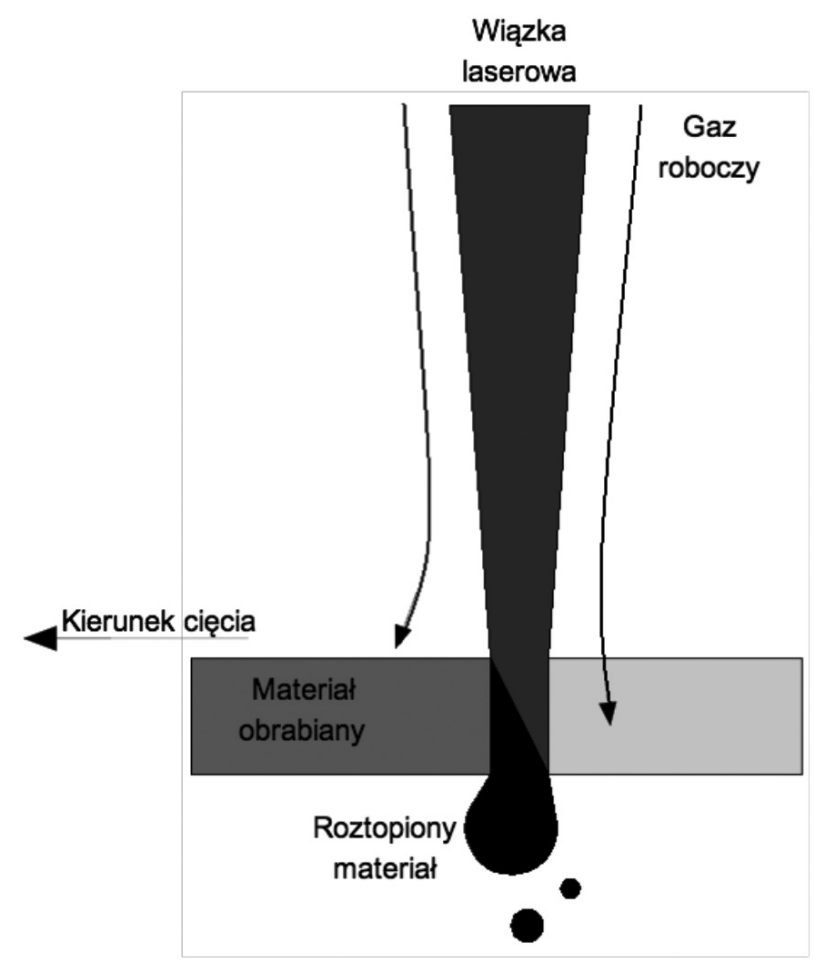

Rys. 5. Schemat procesu cięcia laserowego ze stapianiem i wydmuchiwaniem materiału

Fig. 5. A schematic of laser fusion cutting process

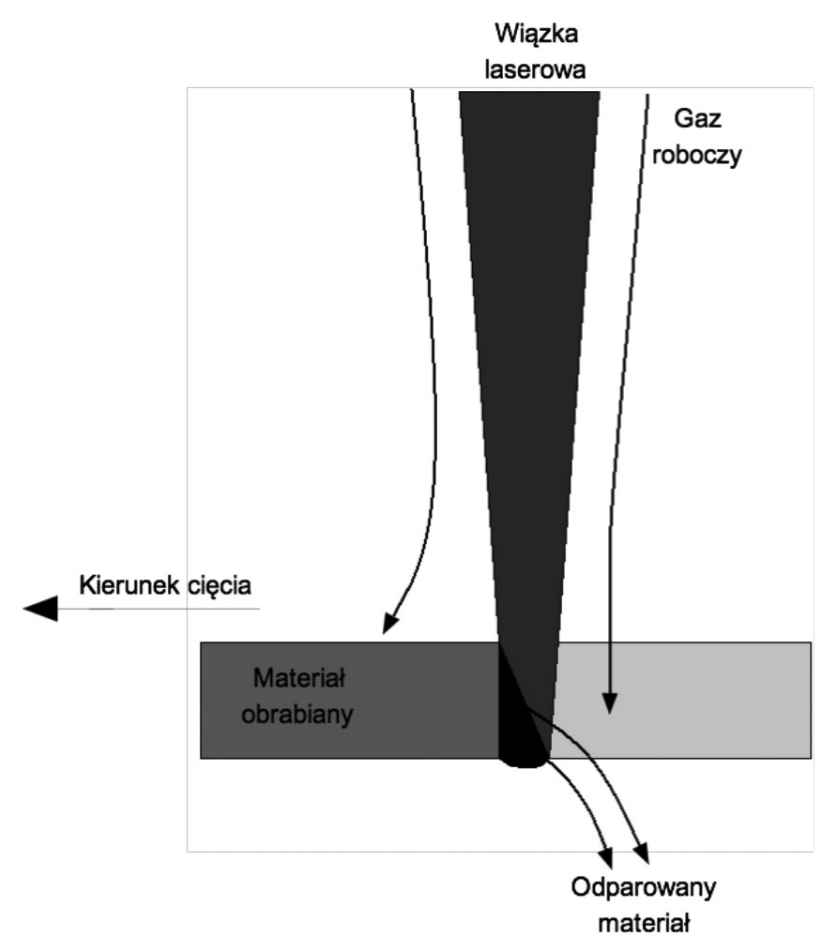

Rys. 6. Schemat procesu cięcia laserowego z odparowaniem materiału

Fig. 6. A schematic of laser sublimation cutting process

chodzące w szczelinie ciecia powodują intensyfikację usuwania produktów cięcia z szczeliny.

Proces cięcia laserowego $\mathrm{z}$ odparowaniem materiału stosowany jest zazwyczaj do materiałów takich jak tworzywa sztuczne, ceramika, skóra itp., dla których ze względu na wymaganą wysoką gęstość mocy grubość ciętych materiałów ograniczona jest do 5-6 mm. W odniesieniu do metali, charakteryzujących się wysoką przewodnością cieplną zalecane jest ograniczenie tej grubości do $3 \mathrm{~mm}$ [5]. W przypadku obróbki materiałów łatwopalnych należy stosować azot lub argon, które są nieaktywne. 


\section{Podsumowanie}

Cięcie laserowe jest obecnie jedną z najszerzej rozpowszechnionych technologii cięcia termicznego praktycznie wszystkich materiałów stosowanych w budowie maszyn. Zastosowanie silnie skoncentrowanego promieniowania laserowego pozwala na precyzyjne i bardzo szybkie wykonywanie elementów, szczególnie w produkcji jednostkowej. Ciągłe zwiększanie wymogów dotyczących dokładności i jakości wykonania zwiększa obszar zastosowania cięcia laserowego jednocześnie eliminując inne technologie wykonania, nawet w produkcji seryjnej. Prawidłowy dobór parametrów procesu pozwala na uzyskanie krawędzi cięcia elementów nie wymagających dalszej - dodatkowej obróbki. Mimo wysokich kosztów zakupu urządzenia obserwowany jest ciągły wzrost zastosowania cięcia laserowego. Również ciągły rozwój urządzeń laserowych, uzyskiwanie coraz to krótszej fali promieniowania laserowego zwiększa obszar zastosowania o nowe materiały.

\section{Literatura}

[1] Houldcroft P.: Gas-jet laser cutting. British Welding Journal, August 1967 , s. 443

[2] Steen W. M.: Laser Material Processing, 3rd ed. 2003, Springer-Verlag, London.

[3] Chars L. Caristan: Laser Cutting - Guide for Manufacturing, 2004, SME, AFFT, Dearborn, Michigan.

[4] Ion J.C.: Laser Processing of Engineering Materials: Principles, Procedure and Industrial Application. Elsevier Butterwort- Heinemann, 2005.

[5] Klimpel A.: Technologie laserowe. Wyd. Pol. Śląskiej, 2012.

[6] Karatas C., Keles O., Uslan I., Usta Y.: Laser cutting of steel sheets: Influence of workpiece thickness and beam waist position on kerf size and stria formation. Journal of Materials Processing Technology, no. 172, 2006, 22-29.

[7] Mahrle A., Bartels F. and Beyer E.: Theoretical aspects of the process efficiency in laser beam cutting with fiber lasers. Proc. 27th Int. Congress on Applications of Lasers and Electro Optics, ICALEO 2008 (October 20-23), Temecula, California, USA, 2006, 703-712.

[8] Abdel Ghany K., Newishy M.: Cutting of $1.2 \mathrm{~mm}$ thick austenitic stainless steel sheet using pulsed and CW Nd:YAG laser. Journal of Materials Processing Technology, no. 168 (2005), 438-447.

[9] Thawari G., Sarin Sundar J.K., Sundararajan G., Joshi S.V.: Influence of process parameters during pulsed Nd:YAG laser cutting of nickel-base superalloys. Journal of Materials Processing Technology, no. 170, 2005, 229-239.

[10] Al-Mashikhi S.O., Powell J., Kaplan A.F.H., Voisey K.T.: An explanation of 'striation free' cutting of mild steel by fibre laser. Proceedings of the Fifth International WLT-Conference on Lasers in Manufacturing 2009, Munich, June 2009.

[11] Klimpel A.: Technologia spawania i cięcia metali, Wydawnictwa Naukowo-Techniczne, Warszawa 1999

[12] Banasik M.: Lasery molekularne $\mathrm{CO}_{2} \mathrm{w}$ zastosowaniach spawalniczych, Przegląd Spawalnictwa (Nr 9/2000)

[13] Zowczak W.: Laserowa obróbka ubytkowa, materiały konferencyjne, Warszawa 2003

[14] Powell J. $\mathrm{CO}_{2}$ Laser Cutting, 1998 Springer 